Original research article

\title{
Psychometric properties of the Polish version of the Quality of Discharge Teaching Scale (QDTS) for postpartum mothers
}

\author{
Małgorzata Nagórska *, Dorota Darmochwał-Kolarz \\ University of Rzeszow, Medical College, Institute of Medical Sciences, Rzeszów, Poland
}

\begin{abstract}
Introduction: Childbirth is an important event in the life of the family, and at the same time it is a considerable challenge in the light of new responsibilities. Preparation for motherhood is very important for women and it gives them a sense of security and self-confidence. During the stay in the maternity ward, mothers receive a lot of information from the medical staff about self-care after delivery and childcare. The Quality of Discharge Teaching Scale (QDTS) for postpartum mothers is a tool used to assess the quality of women's health education after delivery.

Aim: The aim of the research was to translate and analyze the psychometric properties of the Polish version of the Quality of Discharge Teaching Scale.

Methods: The study was conducted from June to October 2017 among 142 adult postpartum women on the day of discharge from the maternity ward of Clinical Provincial Hospital no 2 in Rzeszow, Poland. Cross-sectional study and questionnaire technique were used to collect data.

Results: The Cronbach Alpha measure was used to assess the internal consistency of the scale. A Cronbach Alpha value which is greater than 0.7 indicates that the scale has high reliability.

Conclusions: The analysis confirms that in Polish conditions the questionnaire has a very high reliability in assessing the quality of health education of mothers after delivery.
\end{abstract}

Keywords: Discharge; Health education; Perinatal care; Postpartum mothers; QDTS

\section{Introduction}

Pregnancy and childbirth are a special period in the life of every woman and her family, but often these joyful moments are also accompanied by fears related to the new life situation. Postpartum mothers struggle with troublesome symptoms characteristic of the puerperium, such as pain, fatigue or mental lability, and at the same time they have to cope with new responsibilities related to caring for a newborn child. This can be particularly difficult for women who have given birth for the first time. Therefore, support and proper preparation for the new social role are very important in this period, and routine classes on newborn care and parenting should be part of the prenatal program (Gregory et al., 2016).

The World Health Organization has developed recommendations for healthcare professionals on how to deal with mothers and newborns after delivery, where maternal education is indicated as one of the key elements in optimizing the health situation of women and children (WHO, 2014). In Poland, according to the current standard of perinatal care, antenatal education covers issues related to the period of pregnancy, child- birth and puerperium. The framework program of antenatal education in relation to the postpartum period includes topics related to the physiology of puerperium including psychological aspects, breastfeeding and support in lactation, and caring for the newborn at home. Both the standard of perinatal care from 2012 and the standard from 2018 describe in detail the education of women in puerperium at home by environmental midwives (Regulation of the Minister of Health 2012, 2018).

Education on maternal self-care and newborn care is also of great importance. In the first days after delivery (while still in hospital) the care is provided by medical staff. This is intended to prepare women for proper self-care and childcare and to help them acquire the ability to respond to symptoms that may indicate health hazards. In 2012, Augustyniuk et al. developed a standard of postpartum education implemented in maternity wards by midwives to improve the quality of care for mother and child.

They indicate that the proper preparation of mothers for self-care reduces the possibility of serious postpartum complications, and thus the risk of bearing the costs of treatment and hospitalization. This is also the case for newborns; poor care and nursing may result in health problems.

\footnotetext{
* Corresponding author: Małgorzata Nagórska, University of Rzeszow, Medical College, Institute of Medical Sciences, Al. Rejtana 16C, 35-959 Rzeszów, Poland; e-mail: nagorska@ur.edu.pl http://doi.org/10.32725/kont.2021.046 
Therefore, it is worth monitoring and improving the quality of health education during the postpartum period using a standardized tool - Quality of Discharge Teaching Scale new mother form (QDTS). This American scale enables the assessment of health education of postpartum mothers (Weiss and Lokken, 2009; Weiss et al., 2007). The adaptation of this tool to Polish conditions will enable assessment of the quality of services in the field of health education of new mothers. The presented work is part of a larger project in which two other scales were adapted: RHDS and PDCDS (Nagórska and Darmochwał-Kolarz, 2019).

\section{Objectives}

The aim of the study was to translate and analyze the psychometric properties of the Polish version of the Quality of Discharge Teaching Scale (QDTS) of new mothers.

\section{Materials and methods}

\section{Participants}

The study was conducted among postpartum mothers in the Clinical Provincial Hospital No2 in Rzeszow, from June to October 2017. The method of sample selection and data collection as well as the sample size were agreed with the author of the original version. The inclusion criteria were adult mothers (over 18 years), after childbirth or cesarean delivery on the day of discharge, who gave informed consent to participate in the project. The minimum sample size $(N=84)$ was calculated using the G-Power 3.1 Sample Size Estimation Program. Statistical analysis included data from 142 fully completed questionnaires.

\section{Instruments}

The questionnaire developed by the authors was used to collect socio-demographic data, including place of residence, age, education, socio-legal and professional status of the child's parents and obstetric history: type of delivery, parity, method of feeding the newborn in the hospital and date of discharge.

\section{Quality of Discharge Teaching scale - QDTS}

The Quality of Discharge Teaching scale consists of 19 questions enabling the assessment of the quality of postpartum women's health education during the stay in the maternity ward and the skills of educators in this regard. Here, health education is assessed from the patient's perspective. The first 7 pairs of questions (Q1a, Q1b-Q7a, Q7b) were composed in such a way as to enable the assessment of the information obtained by making a comparison in two subscales: (1) the need for information - "how much information did you need", and (2) the information actually obtained - "how much information did you receive." Questions on the subscale for information needed were marked with the letter A - "content needed" (how much information did the new mother need), and questions on the subscale with information received were marked with the letter B "content received" (how much information did the new mother receive). The remaining 12 questions (Q8Q19) form the "content with delivery" subscale and concern the assessment of midwives' skills as educators in the postpartum period. This assessment focuses on such skills as: the ability to actively listen and answer questions, adapting education style to the level of the listener, the sensitivity and empathy of the educators, the ability to strengthen the mother's confidence in self-care, child care, and taking action in emergency situations.
The answer to each question is given by circling on a scale from 0 to 10 with a description explaining the meaning of the numeric scale (e.g. 0 not at all -10 very much or 0 not at all 10 always). The total score is calculated by adding the points obtained in the "content received" and "content with delivery" subscales. The higher the score, the better the assessment. One can also generate the "content difference" subscale by calculating the difference between "content received" and "content needed". The "content difference" subscale can be used as an alternative to "content received" in calculating the total final result (Weiss and Lokken, 2009; Weiss et al., 2007).

\section{Tool translation procedure}

The QDTS tool adaptation procedure was carried out in two stages. The first stage of adaptation involved forward translation of the research tool, and the second - assessing its psychometric properties. The main purpose of this process was cultural adaptation and preparation of a Polish scale ready for practical use (Brzyski, 2012; Drwal, 1990; Wild et al., 2005). The original scale was translated into Polish by two independent translators, and then one version of the translation was created based on a comparison of the two versions. The Polish version has been translated back into English by another translator (back translation). After consulting and agreeing on the amendments suggested by the author, the final Polish version of QDTS was prepared. In terms of graphics, the Polish version does not differ from the original.

\section{Ethical consideration}

The research tool was used with the authors' consent and prepared according to the rules adopted for the language adaptation process. The project received a positive opinion from the Bioethics Committee at the University of Rzeszow (Resolution No 2/4/2017).

\section{Pilot study}

Prior to the actual tests, a pilot study was carried out among 15 postpartum women to ensure that the prepared version of the tool was understandable. The results obtained were used to make the necessary corrections to the content of the questionnaire.

\section{Data collection}

After obtaining the consent from the hospital management, the surveys were carried out from June to November 2017. The surveys were distributed to mothers 3 hours before leaving the hospital by two midwives employed in the ward who volunteered to do so. Patients, who gave informed consent to anonymously participate in the study, returned the completed questionnaires to the interviewers. The questionnaire took about 10 minutes to complete.

\section{Material}

142 patients from the maternity ward participated in the study. Socio-demographic data indicate that the majority of respondents were married women (88\%) and $12 \%$ were single with higher $(52 \%)$ or secondary (34\%) education. Residents of cities constituted $51 \%$ of the respondents, while $49 \%$ were from the surrounding countryside. Most surveyed new mothers were professionally active (70\%) and $92 \%$ of husbands/ partners had jobs. Over half of the women gave physiological birth and $49 \%$ had a Caesarean Section. It was not the first delivery for $63 \%$ of the new mothers, while $37 \%$ were giving birth for the first time. $84 \%$ of the new mothers chose breast feeding. Mothers were discharged on the second (20\%), third 
(38\%) or fourth (35\%) day after delivery depending on the type of delivery, obstetric condition and the general condition of the mother and child (Table 1).

\section{Methods of statistical analysis}

The statistical analysis was carried out with STATISTICA 13 software. The results for each question were presented with descriptive statistics using the mean $(\bar{x})$, standard deviation (SD), minimum and maximum values (Min and Max) and quartile values (Q1, Me, Q3).
All questions were analysed with Pearson's correlation $(R)$, for which the following interpretation of the relationship between parameters was applied: $0.0-0.3$ - no correlation, 0.3-0.4 - weak correlation, 0.4-0.7 - moderate correlation, 0.7-0.9 - strong correlation, 0.9-1.0 - very strong correlation. To analyse a significance coefficient $\alpha=0.05$ was used, which allowed the consideration of statistically significant variables at $p<0.05$

The internal consistency of the scale was measured by the Cronbach Alpha test. A Cronbach Alpha value greater than 0.7 indicates that the scale has high reliability.

Table 1. The characteristics of the sample $(N=142)$

\begin{tabular}{|c|c|c|c|}
\hline Variable & Indicators & $N$ & Percentage \\
\hline \multirow{2}{*}{ Place of living } & City & 72 & $51 \%$ \\
\hline & Village & 70 & $49 \%$ \\
\hline \multirow{2}{*}{ Marital status } & Marriage/Cohabitation & 141 & $99 \%$ \\
\hline & Single mother & 1 & $1 \%$ \\
\hline \multirow{6}{*}{ Educational status } & Primary & 1 & $1 \%$ \\
\hline & Junior high school & 2 & $2 \%$ \\
\hline & Secondary & 48 & $34 \%$ \\
\hline & Vocational & 6 & $4 \%$ \\
\hline & Higher - Undergraduate & 11 & $8 \%$ \\
\hline & Higher - Graduate & 74 & $51 \%$ \\
\hline \multirow{2}{*}{ Occupational situation of mother } & Employed & 99 & $70 \%$ \\
\hline & Unemployed & 43 & $30 \%$ \\
\hline \multirow{3}{*}{ Occupational situation of father } & Employed & 131 & $92 \%$ \\
\hline & Unemployed & 10 & $7 \%$ \\
\hline & I do not know & 1 & $1 \%$ \\
\hline \multirow{2}{*}{ Type of birth } & Vaginal birth & 73 & $51 \%$ \\
\hline & Cesarian section & 69 & $49 \%$ \\
\hline \multirow{2}{*}{ Parity } & Primipara & 53 & $37 \%$ \\
\hline & Multipara & 89 & $63 \%$ \\
\hline \multirow{2}{*}{ Feeding } & Breastfeeding & 119 & $84 \%$ \\
\hline & Bottle & 23 & $16 \%$ \\
\hline \multirow{4}{*}{ Day of discharge } & 2 & 49 & $35 \%$ \\
\hline & 3 & 54 & $38 \%$ \\
\hline & 4 & 29 & $20 \%$ \\
\hline & $>4$ & 9 & $7 \%$ \\
\hline
\end{tabular}

\section{Results}

The Quality of Discharge Teaching Scale (QDTS) questionnaire for assessing the quality of health education before discharge consists of 19 questions with the possibility of marking answers on the Likert scale from 0 to 10 points. The lowest values were recorded for questions on the "content needed" subscale (Q1a-Q7a). It was also noted that the questions related to this subscale had lower results than the results of the "content received" subscale regarding the knowledge received (Q1b-Q7b). The average results ranged from 3.3 to 5.64 for questions from the "content needed" subscale, and from 4.61 to 7.36 for questions from the "content received" subscale. Other questions
(Q8-Q19) ("content delivery" subscale) obtained higher results ranging from 6.15 to 8.87 . The overall assessment of all questions is included in Table 2.

The correlation analysis of the results showed that all the questions correlated positively to one another. Questions correlating the largest number of times were questions $4 \mathrm{~b}, 3 \mathrm{~b}$ (20 correlations), the lowest correlation index was found for the question $5 \mathrm{~b}$ (one correlation). Correlation results for all obtained questions are presented in Table 3.

Statistical analysis with the Alpha Cronbach test for the presented questions was: 0.914 , which indicated a very high index of the results matching with one another. The average correlation between results was 0.326 . The average result for the total results of 19 questions (26 answers in total) reached 
Table 2. Descriptive analysis of QDTS results

\begin{tabular}{|c|c|c|c|c|c|c|c|}
\hline Questions & $\bar{x}$ & SD & Min & $\mathrm{Q}_{1}$ & $\mathrm{Me}$ & $\mathrm{Q}_{3}$ & Max \\
\hline Q1a & 4.45 & 2.86 & 0 & 2 & 5 & 7 & 10 \\
\hline Q1b & 6.45 & 3.19 & 0 & 5 & 8 & 9 & 10 \\
\hline Q2a & 3.30 & 3.22 & 0 & 0 & 3 & 6 & 10 \\
\hline Q2b & 4.61 & 3.56 & 0 & 1 & 5 & 7.5 & 10 \\
\hline Q3a & 5.08 & 3.08 & 0 & 3 & 5 & 7 & 10 \\
\hline Q3b & 6.53 & 3.03 & 0 & 5 & 7 & 9 & 10 \\
\hline Q4a & 5.64 & 3.42 & 0 & 3 & 6 & 9 & 10 \\
\hline Q4b & 6.96 & 3.07 & 0 & 5 & 8 & 10 & 10 \\
\hline Q5a & 3.82 & 3.14 & 0 & 1 & 3 & 6 & 10 \\
\hline Q5b & 7.36 & 2.91 & 0 & 6 & 8 & 10 & 10 \\
\hline Q6a & 4.09 & 3.27 & 0 & 1 & 4 & 7 & 10 \\
\hline Q6b & 4.89 & 3.61 & 0 & 1 & 5 & 8 & 10 \\
\hline Q7a & 3.37 & 3.17 & 0 & 0 & 3 & 6 & 10 \\
\hline Q7b & 4.04 & 3.69 & 0 & 0 & 4 & 7 & 10 \\
\hline Q8 & 7.63 & 2.56 & 0 & 6 & 8 & 10 & 10 \\
\hline Q9 & 8.30 & 2.35 & 0 & 8 & 9 & 10 & 10 \\
\hline Q10 & 8.25 & 2.24 & 0 & 8 & 9 & 10 & 10 \\
\hline Q11 & 8.30 & 2.12 & 0 & 7 & 9 & 10 & 10 \\
\hline Q12 & 8.87 & 1.63 & 2 & 8 & 10 & 10 & 10 \\
\hline Q13 & 8.26 & 2.20 & 0 & 8 & 9 & 10 & 10 \\
\hline Q14 & 8.22 & 2.31 & 0 & 7 & 9 & 10 & 10 \\
\hline Q15 & 8.31 & 2.19 & 0 & 7 & 9 & 10 & 10 \\
\hline Q16 & 6.15 & 3.29 & 0 & 4 & 7 & 9 & 10 \\
\hline Q17 & 7.82 & 2.34 & 0 & 7 & 8 & 10 & 10 \\
\hline Q18 & 7.80 & 2.04 & 2 & 6 & 8 & 10 & 10 \\
\hline Q19 & 7.86 & 2.45 & 0 & 7 & 8 & 10 & 10 \\
\hline
\end{tabular}

166.02 with a standard deviation of 41.63 points. The results for the questions $5 \mathrm{a}$ and $5 \mathrm{~b}$ had the greatest negative effect on the Cronbach's Alpha. The greatest positive impacts were found for questions $3 \mathrm{~b}$ and $4 \mathrm{~b}$. Additionally, the following results of Alpha Cronbach were obtained for the three subscales: "content needed" - 0.853, "content received" - 0.855, "content delivery" - 0.916 .

\section{Discussion}

The birth of a child is a joyful event for a woman and her family, however these positive emotions are frequently accompanied by fears related to the new life situation. Motherhood brings new challenges for mothers, and proper preparation for this role can have a positive effect on self-confidence and significantly facilitate the adoption of a new social role. Fulfilling the role of a mother depends on a woman's experience in interacting with a child and her reliance in the ability to care for it, which in turn affects her sense of self-confidence (Condgen, 2016; Liu et al., 2012). Proper preparation for taking up new tasks may contribute to minimizing the anxiety resulting from inexperience (Augustyniuk et al., 2012). Being able to react to unpredictable situations and knowing where to seek help is important for safety. This comprehensive knowledge is acquired by mothers during their education before discharge from the maternity ward.

Proper postpartum education has measurable benefits for the mother, child and family, and significantly affects the satisfaction with perinatal care (Maloney and Weiss, 2008; Msele et al., 2017; Wagner and Washington, 2016). The quality of the care provided is also influenced by the quality of this education (Chan et al., 2013; Wagner and Bear, 2009; Wagner et al., 2011). Apart from health advantages, proper education also has tangible economic benefits by preventing complications and the related costs of possible treatment or re-hospitalization.

The aim of our study was to translate and analyze the psychometric properties of the Polish version of the Quality of Discharge Teaching Scale - obstetrics form. No tool for assessing the quality of education of postpartum patients was available in Poland, therefore we adapted this validated tool. So far, the scale has been translated into Spanish (Malagon-Maldonado et al., 2017). 
Table 3. The Alpha Cronbach test results for 19 questions from QDTS

\section{QUALITY OF DISCHARGE}

TEACHING SCALEC*

Questions
Mean $=166.02, \mathrm{SD}=41.63 ;$ Valid $N: 135$

Cronbach Alpha: 0.914

Mean correlation between items: 0.3260

Square Alpha when deleted

Q1a. How much information did you need from your nurses about taking care of yourself after you go home?

0.556

0.914

Q1b. How much information did you receive from your nurses about taking care of yourself after you go home?

0.620

0.909

Q2a. How much information did you need from your nurses about your emotions after you go home?

0.619

0.914

Q2b. How much information did you receive from your nurses about your emotions after you go home?

0.750

0.909

Q3a. How much information did you need from your nurses about taking care of your baby after you go home?

0.722

0.911

Q3b. How much information did you receive from your nurses about taking care of your baby after you go home?

Q4a. How much information did you need from your nurses about feeding your baby after you go home?

0.775

0.907

Q4b. How much information did you receive from your nurses about feeding your baby after you go home?

Q5a. How much practice did you need with baby care skills before going home?

Q5b. How much practice did you have with baby care skills before going home?

0.626

0.914

0.746

0.907

0.639

0.915

0.303

0.917

Q6a. How much information did you need from your nurses about who and when to call if you have problems after you go home?

0.664

0.912

Q6b. How much information did you receive from your nurses about who and when to call if you have problems after you go home?

Q7a. How much information did your family member(s) or others need about care for you and your baby after you go home from the hospital?

Q7b. How much information did your family member(s) or others receive about care for you and your baby after you go home from the hospital?

Q8. How much did the information provided by your nurses answer your specific concerns and questions?

Q9. How much did your nurses listen to your concerns?

0.671

0.908

0.671

0.913

Q10. Were your nurses sensitive to your personal beliefs and values?

0.629

0.910

0.591

0.912

0.839

0.910

0.785

0.911

Q11. Did you like the way your nurses taught you about how to care for yourself and your baby at home?

0.785

0.909

Q12. Was the information your nurses provided about caring for yourself and your baby presented to you in a way you could understand?

0.719

0.912

Q13. Did your nurses check to make sure you understood the information and instructions?

0.690

0.911

Q14. Did you receive consistent (the same) information from your nurses, doctors, and other health workers?

0.646

0.913

Q15. Was the information about caring for yourself and your baby given to you at times that were suitable for you?

0.679

0.912

Q16. Was the information you received from your nurses given at times when your family member(s) or others could attend?

0.564

0.910

Q17. Did your nurses help you to feel confident in your ability to care for yourself and your baby at home?

Q18. How confident do you feel that you would know what to do in an emergency?

0.577

0.914

Q19. Did the information your nurses provided about your care and your baby's care at home decrease your anxiety about going home?

0.806

0.909

* (c) Prof. Marianne Weiss, DNSc, RN. 
Discharge education covers all information that the patient received during hospitalization that is useful after leaving the hospital. In the case of postpartum women, it is broad knowledge about self-care and childcare. Preparation for discharge (education) is a comprehensive activity, which may take various forms and consists of the transfer of knowledge, as well as the practical preparation of mothers for independence after leaving the hospital (Knier et al., 2015). As noted by Wagner, planning for discharge begins with the admission of a pregnant woman for childbirth, and the recognition of her needs for education appropriate for her (Wagner and Washington, 2016).

Proper postpartum education has measurable benefits for the mother, child and family, and significantly affects the satisfaction with perinatal care (Maloney and Weiss, 2008; Msele et al., 2017; Wagner and Washington, 2016). The quality of the care provided is also influenced by the quality of this education (Chan et al., 2013; Wagner and Bear, 2009; Wagner et al., 2011). In addition to health education, proper education also has measurable economic benefits by preventing complications and the related costs of possible treatment or re-hospitalization.

WHO recommends that mothers and newborns remain under the care of medical staff after childbirth in a medical facility for 24 to 48 hours (WHO, 2013). In recent years, the postpartum hospital stay in Poland has been reduced to the necessary minimum (on average 2 days after birth), therefore the time for education is also limited. Medical staff should find appropriate and effective methods of education to properly prepare the mother for discharge (Wagner and Washington, 2016). The new mother is expected to demonstrate knowledge and confidence in her ability to provide adequate care for herself and the newborn baby before discharge (Buchko et al., 2012).

The standard of education for postpartum women and their families proposed by Augustyniuk et al. (2012) contains comprehensive preparation for a new life role and includes:

1. Postpartum woman's care - sharing knowledge on the principles of care and self-care in the postpartum period: the course of physiological puerperium, hygiene, lactation, nutrition, fertility and methods of family planning, dealing with care problems in the puerperium.

2. Newborn care - transferring knowledge in the field of childcare, care and upbringing: neonatal care, adaptation states, bathing, screening tests, immunization, nutrition.

3. Natural feeding - lactation, diet, feeding techniques, medication and lactation.

4. Psychological preparation for parenting: mental health of parents. Developing the right relationship between parents and children.

5. Familiarizing parents with the availability of medical care for the mother and child after childbirth.
However, the presented standard for ensuring the parents' safety after discharge is not applicable throughout Poland. In practice, maternity and neonatal departments carry out education according to their own procedures, taking into account the recommendations of scientific societies (Polish Society of Gynecologists and Obstetricians) and the applicable law (Regulation of the Minister of Health, 2018).

The proposed tool for assessing the quality of maternity education takes into account all of the above-mentioned areas from the perspective of a woman. It also allows us to assess the approach and method of providing information by educators and their effectiveness, i.e. the subjective sense of security and readiness of mothers to leave the hospital.

The standardized tool, which is QDTS, gives the possibility of repetitions and comparisons in the long term. It also allows for the identification of deficits in the information provided to postpartum women by staff from the perspective of patients. It is an effective tool to evaluate and improve the quality of health education for postpartum women.

Further research is necessary to obtain a precise diagnosis of the current condition, in order to design, effectively implement and reliably assess the educational activities for postpartum women carried out in Polish hospitals.

\section{Conclusions}

The analysis confirms that the Polish version of the questionnaire has a very high reliability in the assessment of the quality of preparation for discharge of maternity ward patients. In practice, the tool can be used to assess the quality of health education and can contribute to its improvement by indicating areas that need to be supplemented from the mother's point of view. In addition, the tool assesses the skills of midwives as health educators in postnatal care.

\section{Funding}

The study was partially financed under the grant for statutory activity (Research Potential) of the Institute of Clinical and Experimental Medicine, Faculty of Medicine, University of Rzeszow for 2018/2019.

\section{Acknowledgements}

The authors would like to thank Professor Marianne Weiss for permission to use the original tool and for her support during this project. We would also like to thank all the women who voluntary participated in this research.

\section{Ethical aspects and conflict of interests}

The authors have no conflict of interests to declare. 


\section{Psychometrické vlastnosti polské verze dotazníku Quality of Discharge Teaching Scale (QDTS) pro matky po porodu}

\section{Souhrn}

Úvod: Porod je důležitou událostí v životě rodiny a zároveň představuje značnou výzvu vzhledem k novým povinnostem po porodu. Příprava na mateřství je pro ženy velmi podstatná a dodává jim pocit jistoty a sebedůvěry. Během pobytu v porodnici dostávají matky od zdravotnického personálu mnoho informací o péči o sebe po porodu i o péči o dítě. Quality of Discharge Teaching Scale (QDTS) pro matky po porodu je nástroj používaný k hodnocení kvality zdravotní výchovy žen po porodu.

Cíl: Cílem výzkumu bylo přeložit a analyzovat psychometrické vlastnosti polské verze nástroje Quality of Discharge Teaching Scale.

Metody: Studie byla provedena v období od června 2017 do října 2017 mezi 142 dospělými ženami po porodu v den propuštění z porodnice Klinické vojvodské nemocnice č. 2 v polském městě Rzeszowě. Ke sběru dat byla použita průřezová studie a dotazníky. Výsledky: K posouzení vnitřní konzistence nástroje byla použita Cronbachova alfa. Pokud je hodnota Cronbachova alfa vyšší než 0,7, znamená to, že nástroj má vysokou spolehlivost.

Závěr: Analýza potvrdila, že v polských podmínkách má dotazník velmi vysokou spolehlivost při hodnocení kvality zdravotní výchovy matek po porodu.

Klíčová slova: matky po porodu; perinatální péče; propuštění z nemocnice; QDTS; zdravotní výchova

\section{References}

1. Augustyniuk K, Rudnicki J, Grochans E (2012). Standard edukacji poporodowej realizowany w Szkole Matek i Ojców na oddziale neonatologiczno-położniczym. Perinatol Neonatol Ginekol 5(1): 46-50.

2. Brzyski P (2012). Aspekty metodologiczne użycia skal jako instrumentów pomiarowych w badaniach epidemiologicznych. Przegl Lek 69(12): 1287-1292.

3. Buchko BL, Gutshall CH, Jordan ET (2012). Improving quality and efficiency of postpartum hospital education. J Perinat Educ 21(4): 238-247. DOI: 10.1891/1058-1243.21.4.238.

4. Chan ZCY, Wong KS, Lam WM, Wong KY, Kwok YC (2013). An exploration of postpartum women's perspective on desired obstetric nursing qualities. J Clin Nurs 23(1-2): 103-112. DOI: 10.1111/jocn.12093.

5. Congden KA (2016). Perinatal Education and Support Program: Baystate's New Beginnings. J Perinat Educ 25(2): 97-104. DOI: 10.1891/1058-1243.25.2.97.

6. Drwal R (1990). Problemy kulturowej adaptacji kwestionariuszy osobowości. In: Ciechanowicz A (Ed.). Kulturowa adaptacja testów. Warszawa: Polskie Towarzystwo Psychologiczne, Wydział Psychologii Uniwersytetu Warszawskiego, Laboratorium Technik Diagnostycznych im. Bohdana Zawadzkiego.

7. Gregory KD, Niebyl JR, Johnson TR (2016). Preconception and prenatal care: part of the continuum. In: Gabbe $S$, Niebyl J, Simpson J, Landon M, Galan H, Jauniaux E, et al. (Eds). Obstetrics: normal and problem pregnancies. 7th ed. Philadelphia: Elsevier Sounders, pp. 101-124.

8. Knier S, Stichler JF, Ferber L, Catterall K (2015). Patients' perceptions of the quality of discharge teaching and readiness for discharge. Rehabil Nurs 40(1): 30-39. DOI: 10.1002/rnj.164.

9. Liu CC, Chen YC, Yeh YP, Hsieh YS (2012). Effects of maternal confidence and competence on maternal parenting stress in newborn care. J Adv Nurs 68(4): 908-918. DOI: 10.1111/j.1365-2648.2011.05796.x.

10. Malagon-Maldonado G, Connelly CD, Bush RA (2017). Predictors of readiness for hospital discharge after birth: Building evidence for practice. Worldviews Evid Based Nurs 14(2): 118-127. DOI: 10.1111/wvn.12208.
11. Maloney LR, Weiss ME (2008). Patients' perceptions of hospital discharge informational content. Clin Nurs Res 17(3): 200-219. DOI: $10.1177 / 1054773808320406$

12. Mselle LT, Aston M, Kohi TW, Mbekenga C, Macdonald D, White M, et al. (2017). The challenges of providing postpartum education in Dar es Salaam, Tanzania: narratives of nursemidwives and obstetricians. Qual Health Res 27(12): 17921803. DOI: $10.1177 / 1049732317717695$.

13. Nagórska M, Darmochwal-Kolarz D (2019). The adaptation of Polish version of the Readiness for Hospital Discharge Scale (RHDS) for postpartum mothers. Ginekol Pol 90(7): 376-380. DOI: $10.5603 / G P .2019 .0065$.

14. Regulation of the Minister of Health of 20 September 2012 on the standards of medical procedure for the provision of health services in the field of perinatal care provided to a woman during physiological pregnancy, physiological childbirth, puerration and care for a newborn, Dz.U. 2012 poz. 1100 z późn. zm. [online] [cit. 2021-04-03]. Available at: http://isap. sejm.gov.pl/isap.nsf/DocDetails.xsp?id=WDU20120001100 (Polish).

15. Regulation of the Minister of Health of 16 August 2018 on the organizational standard of perinatalcare, Dz.U. 2018 poz. 1756. [online] [cit. 2021-04-03]. Available at: http://isap.sejm.gov.pl/ isap.nsf/DocDetails.xsp?id=WDU20180001756 (Polish).

16. Wagner DL, Bear M (2009). Patient satisfaction with nursing care: A concept analysis within a nursing framework. J Adv Nurs 65(3): 692-701. DOI: 10.1111/j.1365-2648.2008.04866.x.

17. Wagner DL, Washington C (2016). Patient Satisfaction with Postpartum Teaching Methods. J Perinat Educ 25(2): 129-136. DOI: 10.1891/1058-1243.25.2.129.

18. Wagner DL, Bear M, Davidson NS (2011) Measuring patient satisfaction with postpartum teaching methods used by nurses within the interaction model of client health behavior. Res Theory Nurs Pract 25(3): 176-190. DOI: 10.1891/15416577.25.3.176.

19. Weiss ME, Lokken L (2009). Predictors and Outcomes of Postpartum Mothers' Perceptions of Readiness for Discharge after Birth. J Obstet Gynecol Neonatal Nurs 38(4): 406-17. DOI: $10.1111 /$ j.1552-6909.2009.01040.x.

20. Weiss ME, Piacentini LB, Lokken L, Ancona L, Archer J, Gresser S, et al. (2007). Perceived readiness for hospital discharge in adult medical-surgical patients. Clin Nurs Spec 21(1): 31-42. DOI: 10.1097/00002800-200701000-00008. 
21. Wild D, Grove A, Martin M, Martin M, Eremenco S, McElroy S, et al. (2005). Principles of good practice for the translation and cultural adaptation process for patient-reported outcomes (PRO) measures: report of the ISPOR Task Force for Translation and Cultural Adaptation. Value Health 8(2): 94-104. DOI: $10.1111 /$ j.1524-4733.2005.04054.
22. WHO (2013). Postnatal care of the mother and newborn. Geneva, Switzerland. [online] [cit. 2021-04-03]. Available at: https://www.healthynewbornnetwork.org/hnn-content/ uploads/Postnatal_Care_Guidelines_web_v2.pdf

23. WHO (2014). WHO recommendations on postnatal care of the mother and newborn. [online] [cit. 2021-04-03]. Available at: https://apps.who.int/iris/handle/10665/97603 